\title{
PAY EQUITY AND ARBITRAL RESTRICTIONS UNDER THE PUBLIC SERVICE EMPLOYEE RELATIONS ACT
}

\author{
IAN B. McKENNA*
}

The Public Service Employee Relations Act (PSERA)' substitutes arbitration for strikes or lockouts for the resolution of bargaining disputes. The Act removes from arbitration the following issues: ${ }^{2}$

(a) the organization of work, the assignment of duties and the determination of the numbers of employees of an employer;

(b) the systems of job evaluation and allocation of individual jobs and positions within the systems;

(c) selection, appointment, promotion, training, or transfer;

(d) pensions.

Initial anxiety over the potentially negative impact of arbitral restrictions on effective collective bargaining ${ }^{3}$ appeared to be allayed somewhat, by an early decision of the Public Service Employee Relations Board (PSERB). In the Olds College case 4 , the PSERB, stated:

It is the opinion of this Board that the prohibitions set forth in section $48(2)$ ought to be interpreted in the narrow sense of prohibiting only arbitral items which in substance deal with matters therein specified, and not the procedural or collateral matters related thereto. We believe that this interpretation takes into consideration the historical and legislative framework in which The Public Service Employee Relations Act was promulgated and that such interpretation recognizes the historical relationship between the government and its general service and other employees.

This restrictive approach was endorsed by the PSERB in a subsequent case, when it said: 5

The Public Service Employee Relations Act as a whole was designed to parallel and extend to employers, employees and their bargaining agents, the same rights and obligations that are to be found in legislation goveming private sector employment relationships absent the prohibition of job actions.

Justice Oliver Wendell Holmes once cautioned students of law to attend not to what judges say but to what they $d o$ in fact. ${ }^{6}$ Such remarks are appropriate to the PSERB because, while it has talked about restricting the ambit of section 48(2), it has frequently assigned an unnecessarily wide scope to the statutory restrictions on arbitrability. The initial anxiety voiced by opposition

* Associate Professor, Faculty of Management, University of Lethbridge.

1. R.S.A. 1980, c. P-33, governing bargaining in the Crown Service, Crown hospitals, colleges, universities and various public boards and commissions.

2. Ibid., s.48(2).

3. Legislative Committee Debates on Bill 41, Alberta Hansard, 1977 No. 55, May 17 pp. 1388-1389 per Notley.

4. Alberia Union of Provincial Employees, Branch 63 v. Board of Governors of Olds College (28 September 1979) No. 105-095-502 (P.S.E.R.B.) para. 21. Upheld by the Supreme Court of Canada 136 D.L.R. (3d) I.

5. AUPE and the Board of Governors of Medicine Hat College (unreponed) PSERB, reference. 140-065-502 (Fraser) pp. 8-9. Approach upheld by Hutchison J. upon judicial review, Queen's Bench (Calgary) (unreported) action \#8701-05833.

6. O.W. Holmes, "The Path of the Law" (1897) 10 Harvard L. Rev. 457. 
members in the legislative debate on the PSERA continues to be heard from the judiciary, academics, labour and an I.L.O. investigation committee. ${ }^{7}$

This note examines critically one of a number of cases in which the PSERB failed to act on its purported policy as enunciated in the Olds College case.

In the 1982 negotiations with the Crown, the Alberta Union of Provincial Employees (AUPE) made proposals for equal pay for work of equal value. ${ }^{8}$ In the ensuing impasse, the Crown argued that pay equity is to be excluded from arbitration by virture of section 48(2)(b) of the PSERA. The Crown argued that a pay equity award would require an arbitrator to rule on matters of job evaluation and classification, matters excluded by section 48(2)(b) and conferred upon the jurisdiction of the minister, subject to Cabinet approval, by the Public Service Act. The AUPE contended that the pay equity proposal was essentially a compensation matter and that the issues of job evaluation and classification were merely collateral.

In ruling the proposal non-arbitral, the PSERB reasoned that it would require a systematic and objective process of analyzing and determining the nature and characteristics of the jobs and occupations in the system and their relationships. ${ }^{9}$ The Board agreed that, while such issues were excluded by section 48(2) from arbitration, they could be the subject of a freely negotiated collective agreement.

The PSERB relied on the dictum of Laskin C.J. in the Olds College case: ${ }^{10}$

I see nothing in s.48(2) of the Act to exclude pay issues from the permitted list of arbitral items, $i t$ being conceded that the establishment of a job classification system and the slotting of employees within the job classifications are reserved to the employers so long as these are not used to affect adversely the rates of pay or salary theretofore being paid to the employees.

The Board viewed this as judicial authority for the non-arbitrability of pay equity, which it saw as essentially a job classification and job evaluation issue.

That decision is open to criticism because the PSERB failed to heed Laskin C.J.'s caveat that job evaluation and classification are reserved to the employer "so long as these are not used to affect adversely the rates of pay or salary theretofore being paid to the employees." There is evidence that a significant cause of pay inequity is that job evaluation and classification systems do operate to affect adversely the rates of pay of employees. The author of a Manitoba Department of Labour publication observed that the reason for the traditional undervaluation and underpayment of "women's work" is that:"

... historically, many, if not most, employers using job evaluation have utilized separate

job evaluation systems for different occupational categories such as clerical jobs, manual

7. Reference Re Public Service Employee Relations Act (1987), 38 D.L.R. (4th) 161; K.P. Swan, "Safety Belt or Straight Jacket? Restrictions on the Scope of Public Sector Bargaining" in Essays in Collective Bargaining and Industrial Democracy, University of Lethbridge, (CCH Can. 1983) at 36-37; Alberta Union of Provincial Employees "Proposed Changes to the PSERA" (Submission to Minister of Labour, the Honourable lan Reid, Sept. 1987) at 9-12; Intemational Labour Organization, "Report on a Study and Information Mission to Canada" (Alberta Case No. 1247) The Governing Body Committee on Freedom of Association, Chairman Sir John Wood, C.B.E. (Nov. 1985) para. 77.

8. Reference by AUPE and the Crown in Right of Alberta to PSERB (PSERA section 49) (December 1982) Nos. 140-003-502; 140-015-502, et al (PSERB) at 18-20.

9. Supra, note 8 at 20 .

10. Supra, note 4 at $8-9$ [emphasis added].

11. "Pay Equity and Job Evaluation" (Manitoba Labour, Winnipeg, March 1987) at 7. 
labor jobs and managerial jobs. Thus sex-segregated job families have been treated independently of one another.

The author cited, by way of example, the A.T. \& T. Company ${ }^{12}$, which produced internal pay inequity because it applied, inconsistently, job evaluation criteria between male-dominated and female-dominated jobs. In evaluating its male-dominated managerial job classifications, the Company assigned high point values for customer contact. Yet, in female-dominated telephone operator classifications, the Company assigned virtually no points for customer contact, even though the Company monitored the performance of telephone operators to assess the quality of their assistance to the public. One must conclude with the author that the Company applied its own evaluation criteria inconsistently between male and female-dominated job classifications, to the latter's disadvantage.

The PSERB's ruling failed to acknowledge Chief Justice Laskin's injunction that job evaluation and classification are non-arbitral only if they are not used to adversely affect rates of pay. It also ignored the empirical evidence that job classification and evaluation systems operate as a significant cause of pay inequity.

While the PSERB's approach to pay equity was inconsistent with its policy declaration in the Olds College case, it was not exceptional. As the I.L.O. Investigating Committee learned, with concern, the PSERB has ruled nonarbitrable such issues as job posting, duration of shifts, bumping by seniority across job classifications or geographic locations, access to training, notice of termination, contracting out bargaining unit work and, of course, pay equity. ${ }^{13}$

The PSERB's failure to pursue its purported, restrictive policy on section 48(2) is an unwelcome departure from the policy of the Act. Section 55 specifies arbitral designed for public and private sector comparability and both the PSERB and arbitration boards have acknowledged such comparability as a policy of the $A c t$. A broad application of the section 48 restriction is scarely consistent with a policy of public/private sector comparability. ${ }^{14}$

The PSERB's failure to adhere to its policy of restricting the ambit of section 48(2) raises the prospect of a successful challenge of it as an infringement of the equality section of the Charter of Rights and Freedoms. ${ }^{15}$

12. This example was quoted from Ronnie J. Steinberg, "Job Evaluation and Methodologies and Comparable Worth Policy" (unpublished). Paper presented at Seminar, New Concepts and Research Directions in Pay Determination, Comell University, 1984.

13. I.L.O., supra, note 7, para. 77.

14. Supra, note 5 .

15. Canadian Charter of Rights and Freedoms, Part I of the Constitution Act, 1982, being Schedule B of the Canada Act 1982 (U.K.), 1982, c.11, s.15. 